\title{
НАУКОВЕ ОБГРУНТУВАННЯ МЕТОДУ РОЗРАХУНКОВОЇ ОЦІНКИ КЛАСУ ВОГНЕСТІЙКОСТІ БУДІВЕЛЬНИХ КОНСТРУКЦІЙ КАБЕЛЬНИХ ТУНЕЛІВ
}

https://doi.org/10.33269/nvcz.2021.2.20-29

Нуянзін O. M..$^{*}$, ORCID ID 0000-0003-2527-6073

Самченко T. B. ${ }^{2}$, ORCID iD 0000-0003-3702-8296

Нуянзін B. M. ${ }^{1}$, ORCID iD 0000-0003-4785-0814

Майборода A. O1., ORCID iD 0000-0001-6108-9772

*E-mail : alexandrnuyanzin@gmail.com

1Черкаський інститут пожежної безпеки імені Героїв Чорнобиля Національного університету цивільного захисту України

2/нститут державного управління та наукових досліджень з цивільного захисту, Україна

ІНФОРМАЦІЯ ПРО СТАТТЮ

Надійшла до редакції: 29.09.2021

Пройшла рецензування: 04.11.2021

КЛЮЧОВІ СЛОВА:

кабельний тунель, температурний

режим пожежі, комп'ютерне

моделювання, будівельні

конструкції, клас вогнестійкості.

\begin{abstract}
АНОТАЦІЯ
У цій роботі розраховано температурні режими прогрівання залізобетонних огороджувальних конструкцій різної товщини кабельного тунелю за постійних значень питомої енергії згоряння пожежного навантаження, площі поперечного перерізу кабельного тунелю та горизонтальної складової швидкості руху повітря. За результатами наукової розвідки обґрунтовано та перевірено алгоритм розрахунку, а також розроблено на його основі метод розрахункової оцінки класу вогнестійкості будівельних конструкцій кабельних тунелів, що базується на математичному моделюванні. У разі обчислення будуються розподіли температури по перерізу огородження кабельного тунелю у час, який відповідає необхідному класові вогнестійкості, та визначається відповідність заданій межі вогнестійкості.
\end{abstract}

Постановка проблеми. Ще 370 -х років минулого століття загострилася проблема пожежної безпеки електричних кабелів та кабельних споруд через зростання кількості пожеж на атомних станціях (АЕС), теплових електростанціях та інших енергетичних об'єктах.

Аналіз меж вогнестійкості будівельних конструкцій тунелів та забезпечення їх відповідності чинним нормативам $\epsilon$ актуальним завданням, оскільки кабельні тунелі відрізняються пожежним навантаженням, видом кабелів, що прокладені у них, геометричною конфігурацією, аеродинамічними характеристиками. Отже, температурні режими пожежі у тунелях можуть відрізнятись і від стандартного, і між собою. У такому разі неможливо гарантувати зазначену відповідність. Сьогодні існує можливість здійснити дослідження 3 вивчення цього питання на основі результатів обчислювальних експериментів, для того щоб не проводити коштовні та трудоємні випробування.

Аналіз останніх досліджень і публікацій. Пожежу умовно поділяють на три стадії: загоряння, розвинене горіння й загасання [1]. Розроблено та відображено у нормативних документах два методи переходу від реальних режимів пожежі до визначеного в нормативах «стандартного» режиму пожежі [2-4].

Для більш точного моделювання пожежі, доцільно застосувати більш складні фізичні моделі, що реалізуються у непростих комп'ютерних програмах [5-7]. В алгоритми цих програм закладені сучасні обчислювальні методи.

У статті [5] та дисертаційній роботі [6] було викладено результати повного факторного експерименту, внаслідок якого 
отримано залежності максимальної температури усередині кабельного тунелю під час пожежі $\left(Q_{e} \max \right)$, тривалості пожежі в певній локальній зоні тунелю $\left(\tau_{1}\right)$ та часу досягнення максимальної температури всередині під час пожежі $\left(\tau_{\max }\right)$, що представлено виразами (1), (2), (3):

$$
\begin{aligned}
& Q_{e \max }=870.59+0.1 * \mathrm{x}_{1}-27.92 * \mathrm{x}_{2}-11.39 * \mathrm{x}_{3}+0.01 * \mathrm{x}_{1} * \mathrm{x}_{2}-5.28 * \mathrm{x}_{2} * \mathrm{x}_{3} \\
& \tau_{1}=48.969+0.002 * \mathrm{x}_{1}-1.44 * \mathrm{x}_{2}+0.0125 * \mathrm{x}_{3}+0.001 * \mathrm{x}_{1} * \mathrm{x}_{2}-0.016 * \mathrm{x}_{2} * \mathrm{x}_{3} \\
& \tau_{\max }=6.55+0.001 * \mathrm{x}_{1}+0.596 * \mathrm{x}_{2}+0.0563 * \mathrm{x}_{3}+0.025 * \mathrm{x}_{2} * \mathrm{x}_{3}
\end{aligned}
$$

де $\mathrm{x}_{1}$ - фактор 1 (пожежне навантаження у перерахунку на $1 \mathrm{~m}^{2}$ кабельного тунелю, МДж/м²); $\mathrm{x}_{2}$ - фактор 2 (площа поперечного перерізу кабельного тунелю, $\mathrm{m}^{2}$ );

$\mathrm{x}_{3}$ - фактор 3 (горизонтальна складова швидкості руху повітря, м/с).

Доцільно спрямувати подальшу роботу на дослідження вогнестійкості будівельних конструкцій кабельних тунелів за визначених за рівняннями температурних режимів пожежі у тунелі та розробити відповідну методику [5-6].

Методи дослідження. Комп'ютерне моделювання та теоретичні дослідження, проведені на основі системи диференціальних рівнянь Нав'є-Стокса для середовищ, рівнянь теплопровідності Фур'є, а також рівнянь теплообміну у твердих, газоподібних тілах та напруженодеформованого стану твердих будівельних матеріалів в умовах нагрівання під час пожежі. Для їх розв'язання було використано метод граничних (кінцевих) елементів, а також методи оброблення розрахункових даних.

Метою статті $\epsilon$ наукове обгрунтування алгоритму розрахунку та розроблення на його підгрунті методу розрахункової оцінки класу вогнестійкості будівельних конструкцій кабельних тунелів, що базується на математичному моделюванні.

Виклад основного матеріалу. Для математичного опису температурного режиму пожежі на гілці, що зростає, запропоновано використовувати формулу, яка наведена нижче i $\epsilon$ удосконаленою модифікацією формули стандартного температурного режиму пожежі відповідно до стандарту [2] та робіт [1;7], що було масштабовано 3 урахуванням результатів, які отримані у попередніх дослідженнях [5-7].

$$
\Theta_{p}=20+345 \frac{\Theta_{e \max }-20}{\Theta_{\max }} \lg [8 t+1]
$$

де значення масштабування максимальної середньооб'ємної температури пожежі у формулі (4) визначається за виразом:

$$
\Theta_{\max }=20+345 \lg \left[8 \tau_{\max }+1\right]
$$

Для представлення гілки, що спадає, температурного режиму пожежі можна використати формулу, яка відповідає лінійній залежності зменшення температури [6]:

$$
\Theta_{c}=\Theta_{e \max }-\frac{\Theta_{e \max }-20}{\tau_{l}-\tau_{\max }}\left(t-\tau_{\max }\right)
$$

Так:

$Q_{e \max }$ - максимальна середньооб'ємна температура;

$\tau_{\max }$ - час досягнення середньооб'ємної максимальної температури;

$\tau_{l}-$ тривалість пожежі.

Вказані параметри обчислюються за виразами регресій, що були одержані після проведення повного факторного експерименту [5].

На рис. 1-3 наведені температурні режими пожеж, що були отримані для різних вхідних даних щодо конструкції та пожежного навантаження кабельних тунелів. 


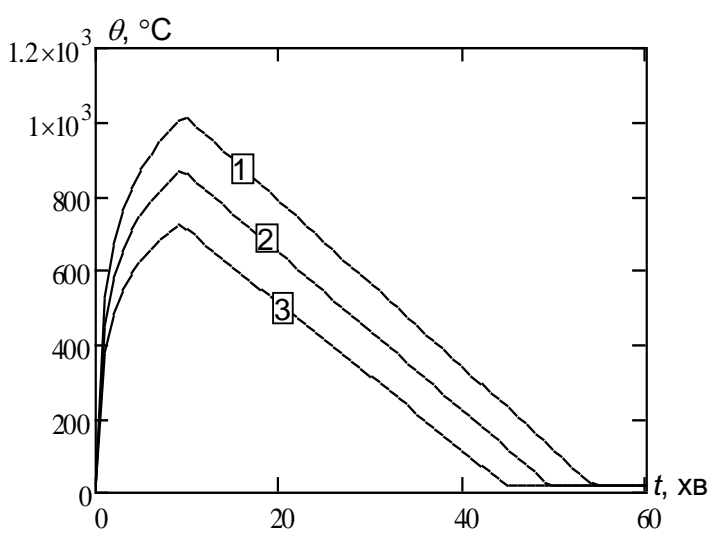

Рисунок 1 - Графіки температурних режимів пожежі за різних значень питомої теплоти згоряння пожежного навантаження (за незмінних значень площі поперечного перерізу тунелю $\mathrm{S}=3.64 \mathrm{~m}^{2}$ та горизонтальної складової швидкості руху повітря у ньому $\mathrm{v}_{\mathrm{x}}=2.5 \mathrm{M} / \mathrm{c}$ ):

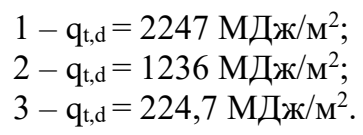

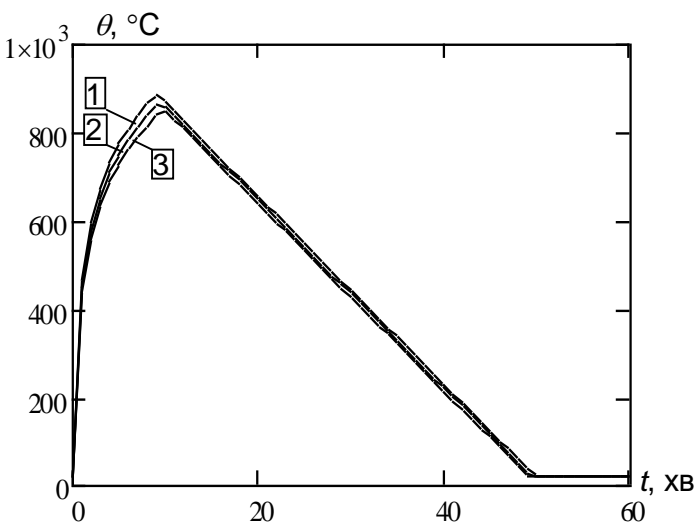

Рисунок 2 - Графіки температурних режимів пожежі за різних значень площі поперечного перерізу кабельного тунелю (за незмінних значень горизонтальної складової швидкості руху повітря $\mathrm{v}_{\mathrm{x}}=2.5 \mathrm{~m} / \mathrm{c}$ та питомої теплоти згоряння пожежної навантаги $\mathrm{q}_{\mathrm{t}, \mathrm{d}}=1236$ МДж/ $\left.\mathrm{M}^{2}\right)$ :

$1-\mathrm{S}=2.88 \mathrm{M}^{2}$

$2-\mathrm{S}=3.64 \mathrm{M}^{2}$;

$3-\mathrm{S}=4.4 \mathrm{M}^{2}$.

Аналізуючи графіки, наведені на рис. 1-3, доходимо висновку, що найбільш впливовим фактором у кабельному тунелі у разі визначення температурного режиму пожежі $є$ питома теплота згоряння пожежного навантаження. Менше впливає фактор горизонтальної складової швидкості руху повітря у тунелі.

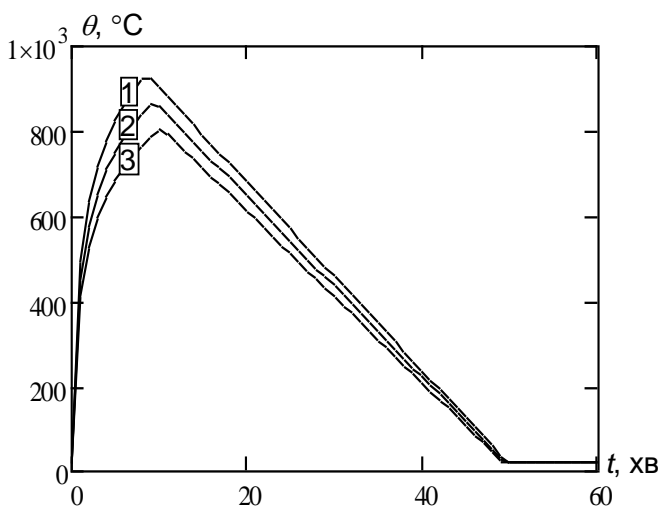

Рисунок 3 - Графіки температурних режимів пожежі за різних значень горизонтальної складової швидкості руху повітря у кабельному тунелі (за незмінних значень площі поперечного перерізу тунелю $\mathrm{S}=$ $3.64 \mathrm{~m}^{2}$ та питомої теплоти згоряння пожежної

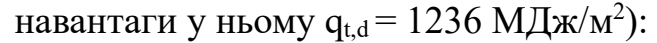

$$
\begin{aligned}
& 1-\mathrm{v}_{\mathrm{x}}=0 \mathrm{~m} / \mathrm{c} ; \\
& 2-\mathrm{v}_{\mathrm{x}}=2.5 \mathrm{M} / \mathrm{c} ; \\
& \left.3-\mathrm{v}_{\mathrm{x}}=5 \mathrm{~m} / \mathrm{c}\right) .
\end{aligned}
$$

I найменш впливовим фактором $\epsilon$ площа поперечного перерізу тунелю у межах визначеного діапазону, що був розглянутий у цій роботі.

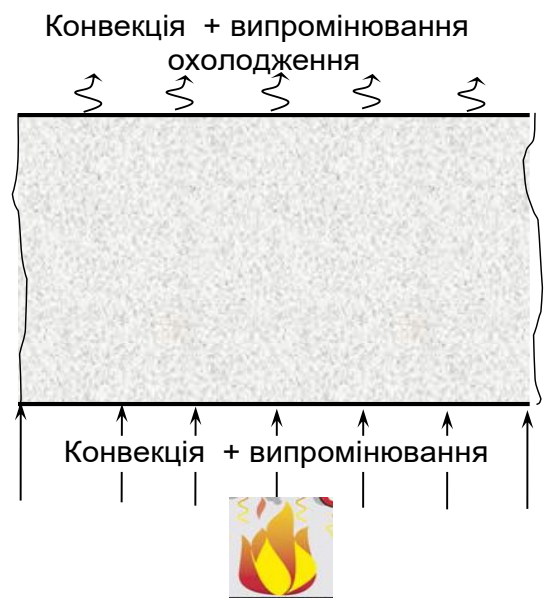

Рисунок 4 - Розрахункова схема до теплового розрахунку огороджувальних конструкцій кабельного тунелю

Для здійснення розрахункової оцінки вогнестійкості огороджувальних залізобетонних конструкцій кабельних тунелів у разі використання розглянутих температурних режимів пожежі має бути визначено температуру прогріву огородження тунелю у будь-який момент часу пожежі. За таких умов конструкція може бути представлена у вигляді нескінченної пластини кінцевої товщини, 
що обігрівається з одного боку, і тоді можна використати розрахункову схему, яка наведена на рис. 4.

Для обчислення температури прогрівання огороджувальних конструкцій тунелів застосовується усталений підхід 3 використанням як базової моделі теплопровідності [3-7], що має вигляд (7).

$$
c_{p, c}(\theta) \rho_{c}(\theta) \frac{\partial \theta}{\partial t}=\frac{\partial}{\partial x}\left(\lambda_{c}(\theta) \frac{\partial \theta}{\partial x}\right)
$$

де $\lambda_{c}(\theta)$ - коефіцієнт теплопровідності бетону, що залежить від температури, $\mathrm{BT} /\left(\mathrm{M}^{\circ} \mathrm{C}\right)$;

$\rho_{c}(\theta)$ - густина бетону, що залежить від температури, кг $/ \mathrm{M}^{3} ; t-$ час, с;

$c_{p, c}(\theta)$ - питома теплоємність бетону, яка залежить від температури, Дж/(кг $\left.{ }^{\circ} \mathrm{C}\right)$.

Залежні від температури теплофізичні характеристики бетону - коефіцієнт теплопровідності, густина та питома

$$
\left.c_{p}(\theta) \rho_{w}(\theta) \frac{\partial \theta}{\partial t}\right|_{i, k}=c_{p}\left(\theta_{i, k}\right) \rho_{w}\left(\theta_{i, k}\right)\left(\theta_{i, k}+\theta_{i, k+1}\right) \cdot \frac{\theta_{i, k+1}-\theta_{i, k}}{2 \Delta t} .
$$

Вираз часткової похідної правої частини рівняння теплопровідності через теплоємність - встановлені відповідно до рекомендацій стандарту [3].

Інтегрування рівняння нестаціонарної теплопровідності у вказаному записі можливо провести у разі використання обчислювальних методів [3-4]. Для рівняння теплопровідності (7) застосована апроксимація за методом кінцевих різниць [7-8]. Для реалізації метода кінцевих різниць, під час інтегрування нестаціонарного рівняння теплопровідності (7) використаний інтегроінтерполяційний метод, що наведено у [7-8]. За таких умов рівняння нестаціонарної теплопровідності (7) можна записати через лінійні алгебраїчні рівняння. Ліва частина рівняння теплопровідності (7) із частковою похідною за часом за апроксимації кінцевими різницями у зазначеній точці записується у вигляді виразу (8).

$$
\left.\frac{\partial}{\partial x}\left(\lambda(\theta) \frac{\partial \theta}{\partial x}\right)\right|_{i, k}=\frac{1}{\Delta x^{2}}\left[a_{x} \theta_{i-1, k}^{x}-\left(a_{x}+b_{x}\right) \theta_{i, k}+b_{x} \theta_{i+1, k}^{x}\right] .
$$

Коефіцієнти у виразі (9) є коротким записом множників із коефіцієнтом теплопровідності та обчислюються у разі

$$
a=\frac{\lambda_{w}\left(\theta_{i-1}\right) \lambda_{w}\left(\theta_{i}\right)}{\lambda_{w}\left(\theta_{i-1}\right)+\lambda_{w}\left(\theta_{i}\right)}, b=\frac{\lambda_{w}\left(\theta_{i-1}\right) \lambda_{w}\left(\theta_{i}\right)}{\lambda_{w}\left(\theta_{i-1}\right)+\lambda_{w}\left(\theta_{i}\right)} .
$$

Формули 8-10 надають можливість апроксимувати рівняння теплопровідності (7) алгебраїчними рівняннями у кінцевих різницях. Рівняння записуються у вигляді рекурентних формул для області вузлів розрахункової сітки у $(\mathrm{k}+1)$-тий момент часу відповідно до показників температур, отриманих попередньо у k-тий момент часу.
Зазначені рекурентні формули мають неявний вигляд та розв'язуються як рівняння.

Застосовуючи прийняті математичні моделі теплопередачі було проведено розрахунок температури у перерізі огородження із різною товщиною. Товщина варіювалася у межах, як наведено на рис. 5. 


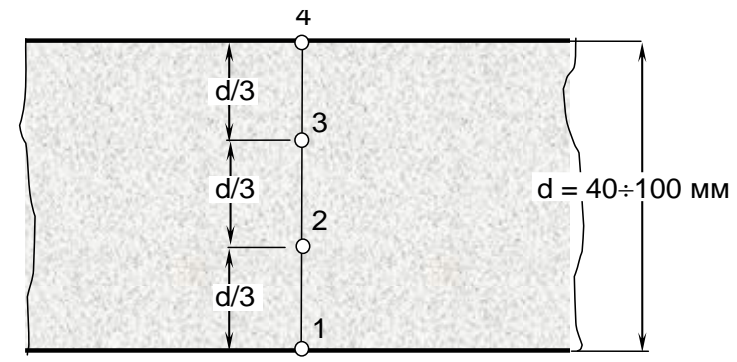

Рисунок 5 - Схема розташування контрольних точок для температурних показників їх прогрівання на загальному вигляді конструктивної розрахункової схеми огороджувальних конструкцій кабельних тунелів

Для розв'язання задачі теплопровідності відповідно до методу кінцевих різниць необхідно задати початкові дані. У розробленій методиці були встановлені такі початкові дані:

початкова температура $\theta_{0}=20^{\circ} \mathrm{C}$;

часовий крок інтегрування $-\Delta \mathrm{t}=60 \mathrm{c}$;

просторовий крок інтегрування $\Delta \mathrm{x}=$ $0.005 \mathrm{M}$.

Як приклад алгоритму застосування розробленої методики (як режиму пожежі) була використана температурна крива 2, що наведена на рис. 1, вона відповідає середнім значенням характеристик кабельних тунелів. Загалом температурний режим пожежі визначається для конкретного тунелю та залежить від його характеристик: пожежного навантаження, виду кабелів, що прокладені, геометричної та аеродинамічної конфігурацій.

Після проведення розрахунків 3 використанням табличного процесора Microsoft Excel були отримані результати у вигляді температурних режимів, наведених на рис. 6.

Згідно 3 аналізом результатів, наведених на рис. 6, температура на обігрівній стороні під впливом прийнятого температурного режиму пожежі (у цьому випадку крива 2 (рис. 1), яку було обрано для прикладу розрахунку за методикою) у кабельному тунелі не перевищує $400{ }^{\circ} \mathrm{C}$. Це свідчить про те, що умови прогрівання за вказаного режиму є набагато м'якшими за умови стандартного температурного режиму пожежі.
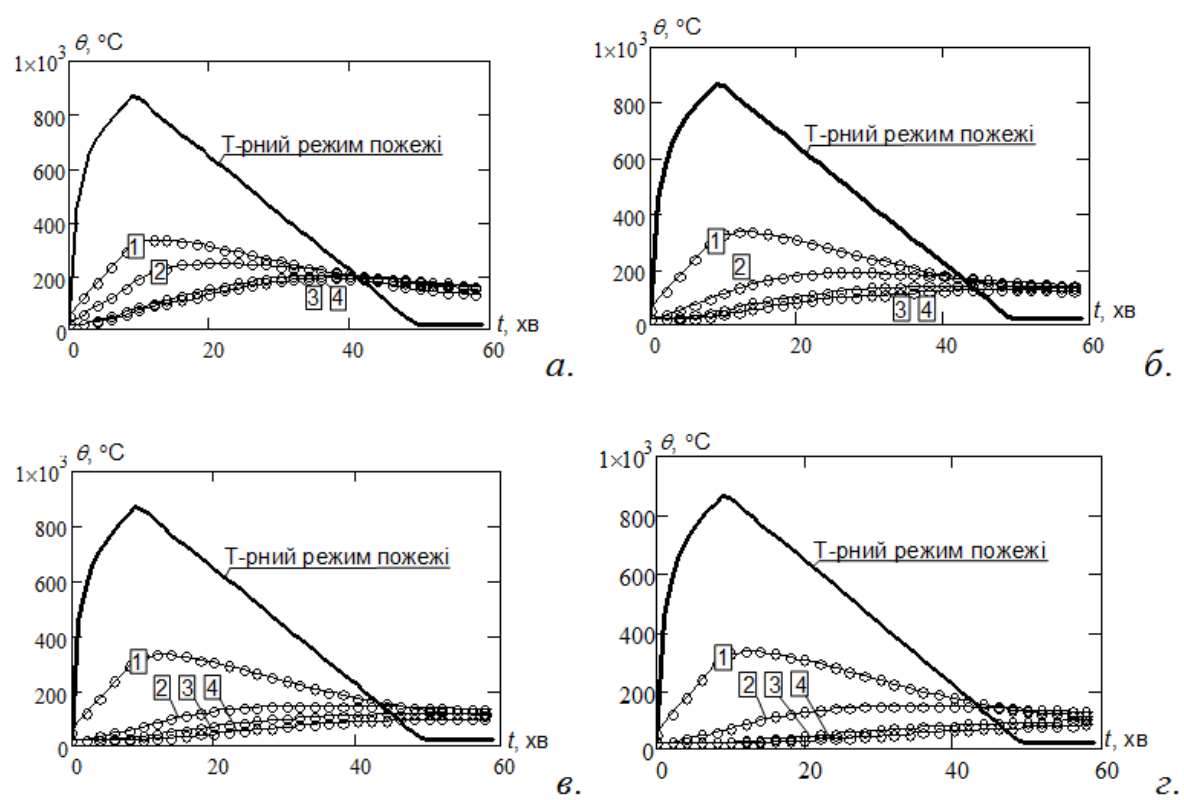

Рисунок 6 - Температурні режими прогрівання залізобетонних огороджувальних конструкцій кабельного тунелю (числові позначення відповідають номерам точок зі схеми на рис. 5) за постійних значень площі поперечного

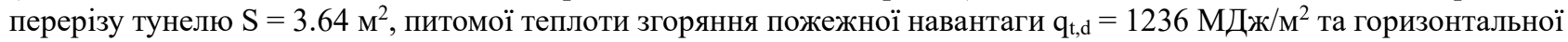
складової швидкості руху повітря $\mathrm{v}_{\mathrm{x}}=2.5 \mathrm{~m} / \mathrm{c}$ для різної товщини конструкції:

а) $40 \mathrm{мм}$; б) $60 \mathrm{мм}$; в) $80 \mathrm{Mм}$; г) $100 \mathrm{Mм}$ 
Для порівняння отриманих результатів, наведених на рис. 6, були проведені розрахунки для теплового впливу пожежі із

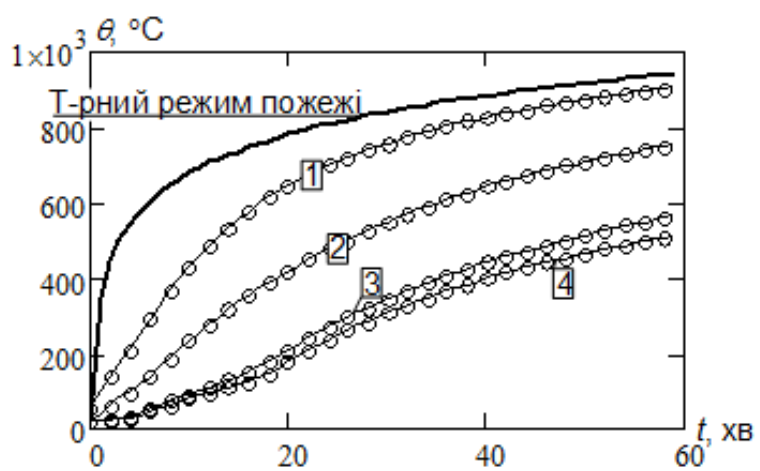

a.

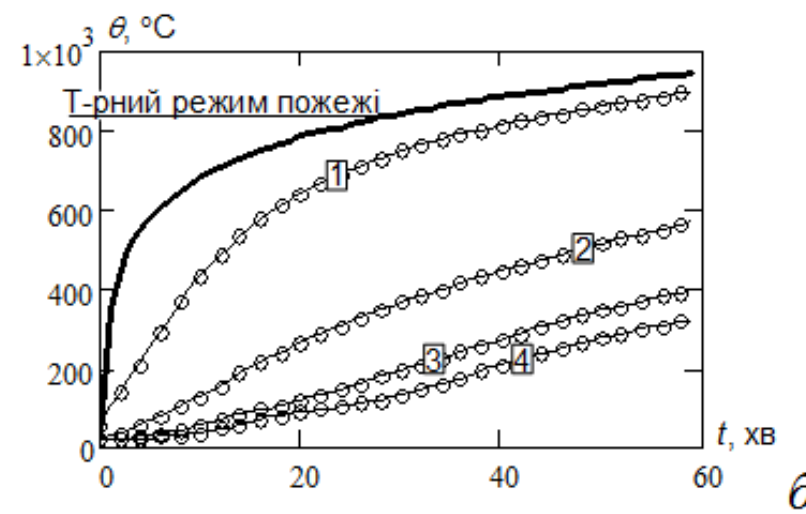

стандартним температурним режимом. Отримані результати наведені на рис. 7.

$\sigma$.

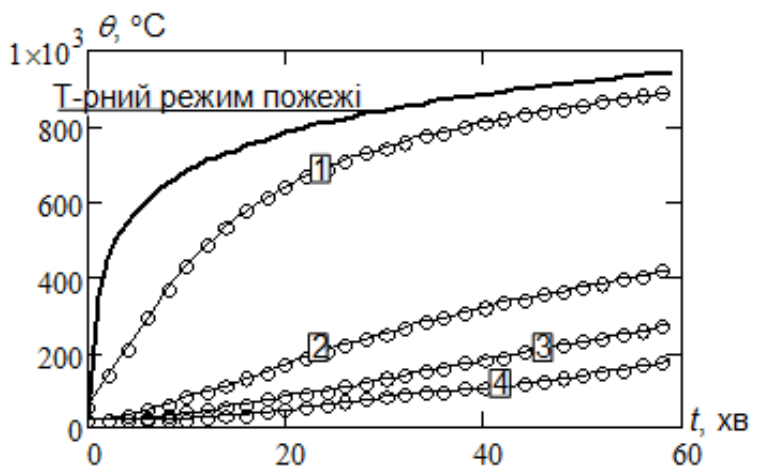

b.

Рисунок 7 - Температурні режими прогрівання залізобетонних огороджувальних конструкцій кабельного тунелю (числові позначення відповідають номерам точок зі схеми на рис. 5) за умов стандартного температурного режиму пожежі для різної товщини конструкції:

а) $40 \mathrm{мм}$; б) $60 \mathrm{мм}$; в) $80 \mathrm{мм}$; г) $100 \mathrm{мM}$

3 огляду на аналіз результатів, наведених на рис. 7, температура на обігрівній стороні під впливом прийнятого температурного режиму пожежі у кабельному тунелі вища за $400{ }^{\circ} \mathrm{C}$. Це свідчить про те, що можуть бути обгрунтовані більш м'які умови пожежі i відповідно вища вогнестійкість. Для оцінки класу вогнестійкості огороджувальних залізобетонних конструкцій кабельного тунелю були побудовані розподіли температури по перерізу цих конструкцій. Побудовані розподіли наведені на рис. 8. Аналізуючи графіки на рис. 8, можна побачити, що лише огородження із товщиною стінки 40 мм не відповідає вимогам щодо класів вогнестійкості ЕI 30, EI 45 та ЕI 60, оскільки температура на необігрівній стороні стінок огороджувальних конструкцій досягає значення, що більше за $140{ }^{\circ} \mathrm{C}$ (вважаємо цілісність огороджувальних конструкцій безпечною за умови дотримання вимог стандарту [2-4] щодо сушки та твердіння бетону).

3 метою порівняння отриманих результатів, що наведені на рис. 8, були проведені розрахунки для теплового впливу пожежі зі стандартним температурним режимом. Було отримано результати, наведені на рис. 9. 

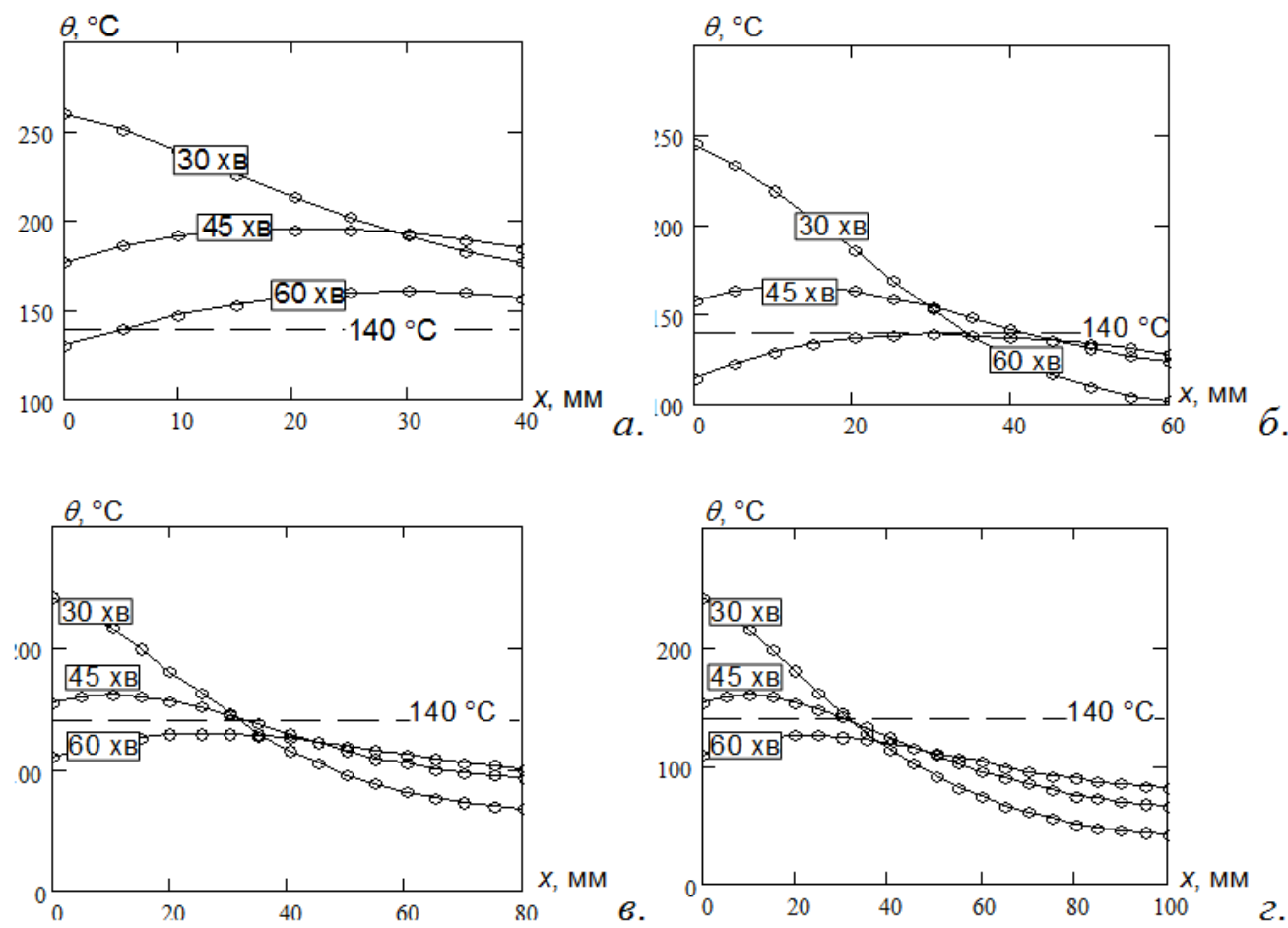

Рисунок 8 - Температурно-часові розподіли у перерізах залізобетонних огороджувальних конструкцій кабельного тунелю за постійних значень горизонтальної складової швидкості руху повітря $\mathrm{v}_{\mathrm{x}}=2.5 \mathrm{~m} / \mathrm{c}$, площі поперечного перерізу тунелю $\mathrm{S}=3.64 \mathrm{~m}^{2}$ та питомої теплоти згоряння пожежної навантаги

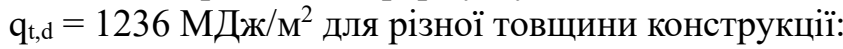

а) 40 мм; б) 60 мм; в) 80 мм; г) 100 мм
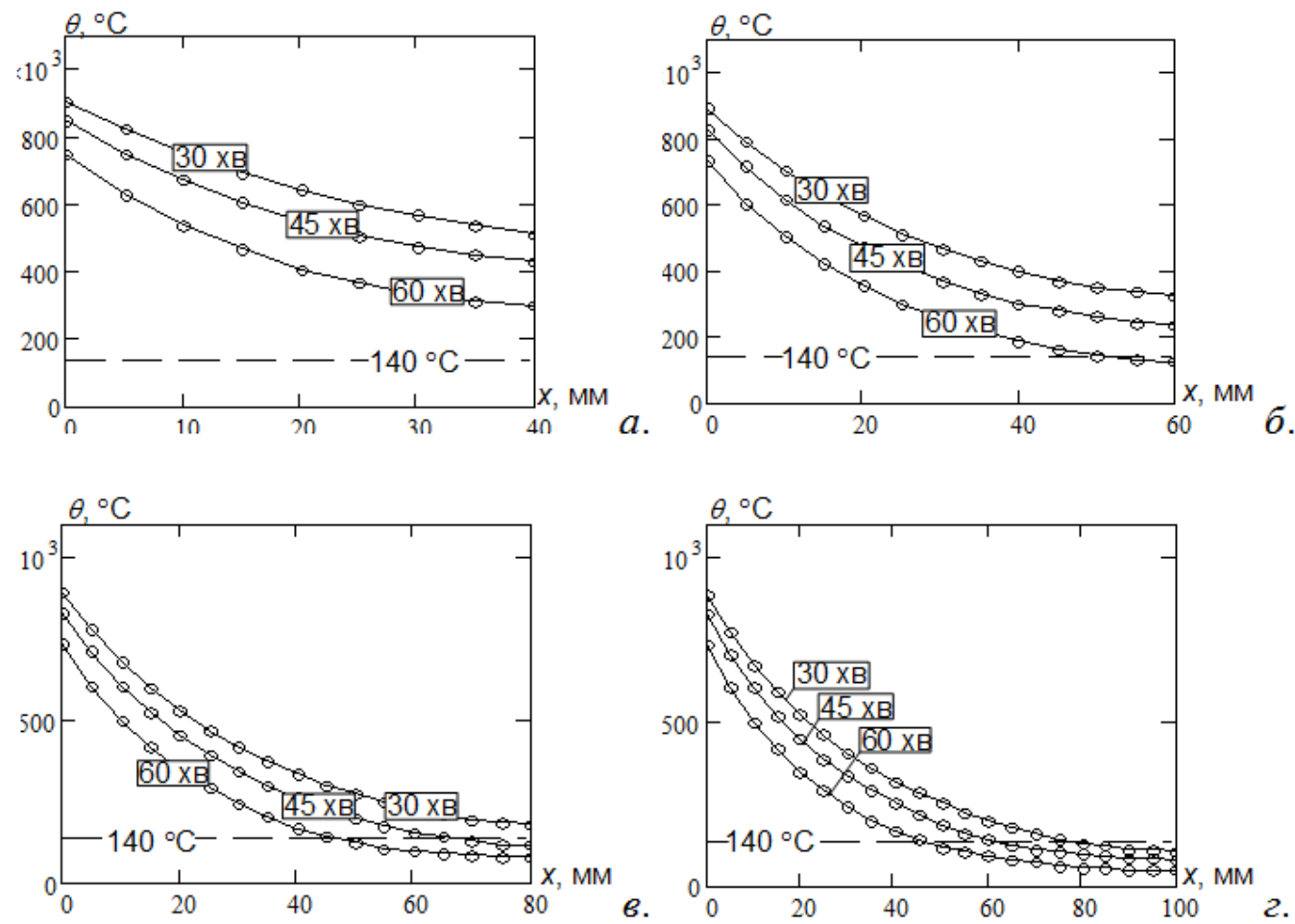

Рисунок 9 - Температурно-часові розподіли у перерізах залізобетонних огороджувальних конструкцій кабельного тунелю за умов стандартного температурного режиму пожежі із товщиною:

а) 40 мм; б) 60 мм; в) 80 мм; г) 100 мм 
Згідно 3 аналізом графіків (рис. 9) тільки огородження кабельного тунелю товщиною 100 мм задовольняє вимоги усіх класів вогнестійкості EI 30, EI 45 та ЕI 60, тоді як стінки тунелю товщиною 80 мм відповідають ЕI 30 та ЕI 45, стінки тунелю товщиною 60 мм - тільки ЕI 30. Викладене показує переваги запропонованого підходу, оскільки дає змогу обгрунтувати вищі класи вогнестійкості для огородження 3 товщиною меншою за 80 мм.

3 огляду на проведені дослідження було запропоновано рекомендації щодо розрахункової оцінки вогнестійкості залізобетонних огороджувальних конструкцій кабельних тунелів. Розроблена методика містить у своїй основі такі процедури:

1. За формулами (1) - (3) визначаються параметри для побудування температурної кривої режиму пожежі у кабельному тунелі: максимальна температура пожежі всередині, час іii досягнення, а також тривалість пожежі.

2. За формулами (4) - (6) будується температурна крива режиму пожежі у кабельному тунелі.

3. У результаті розрахунку будуються розподіли температури у перерізі огородження кабельного тунелю в час, що відповідає необхідному класу вогнестійкості.

4. Якщо температура на необігрівній стороні не перевищує $140{ }^{\circ} \mathrm{C}$, можна робити висновок, що цілісність та теплоізолювальна здатність відповідають зазначеному класові вогнестійкості.

\section{Висновки та напрями подальших досліджень.}

1. Розраховано температурні режими прогрівання залізобетонних огороджувальних конструкцій кабельного тунелю (див. рис. 6) за постійних значень питомої площі поперечного перерізу тунелю $\mathrm{S}=3.64 \mathrm{~m}^{2}$, теплоти згоряння

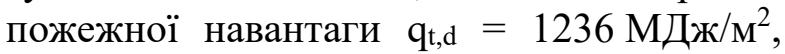
горизонтальної складової швидкості руху повітря в тунелі $\mathrm{v}_{\mathrm{x}}=2.5 \mathrm{~m} / \mathrm{c}$ для товщини конструкцій: 40 мм; 60 мм; 80 мм; 100 мм.

2. Проведено розрахунок межі вогнестійкості будівельних конструкцій стінки огородження кабельного тунелю товщиною: 40 мм; 60 мм; $80 \mathrm{мм}$; 100 мм. Відповідно до цих даних огородження товщиною 100 мм відповідають класам вогнестійкості EI 30, EI 45 та EI 60; стінки тунелю товщиною 80 мм - лише класам вогнестійкості EI 30 та ЕI 45; стінки тунелю товщиною 60 мм - класу вогнестійкості EI 30. Викладене доводить переваги запропонованого підходу, оскільки надає можливість обгрунтувати вищі класи вогнестійкості для конструкцій огородження товщиною меншою за 80 мм.

3. Науково обгрунтовано та перевірено алгоритм розрахунку, а також розроблено на його основі метод розрахункової оцінки класу вогнестійкості будівельних конструкцій кабельних тунелів, що базується на математичному моделюванні. Під час обчислення будуються розподіли температури по перерізу огородження кабельного тунелю у час, який відповідає необхідному класові вогнестійкості. Якщо температура на необігрівній стороні не перевищує $140{ }^{\circ} \mathrm{C}$, можна робити висновок, що цілісність та теплоізолювальна здатність відповідають вказаному класові вогнестійкості. 


\section{СПИСОК ВИКОРИСТАНИХ ДЖЕРЕЛ}

1. Ройтман В. М. Инженерные решения по оценке огнестойкости проектируемых и реконструируемых зданий. М. : Пожарная безопасность и наука, 2001. 382 с.

2. ДСТУ Б В.1.1-4-98 ISO 834:1975.Захист від пожежі. Будівельні конструкції. Методи випробування на вогнестійкість. Загальні вимоги. [Чинний від 1998-10-28]. Київ : Укрархбудинформ, 1999. 21с. (Державний стандарт України).

3. ДСТУ-Н ЕN 1991-1-2:2010 Єврокод 1 : Дії на конструкції - Частина 1-2 : Загальні дії - Дії на конструкції під час пожежі [Чинний від 2014-01-07]. Київ : ДП «Державний науково-дослідний інститут будівельних конструкцій» (НДІБК). 74 с.

4. EN 1992-1-2:2004+A1:2019 (2019) Eurocode 2: Design of concrete structures. Part 1-2 : General rules. Structural fire design, Brussels. $118 \mathrm{p}$.

5. Повний факторний експеримент з визначення температурних режимів пожежі у кабельних тунелях / О. М. Нуянзін та ін. Надзвичайні ситуаиії : попередження та ліквідація. 2019. Т. 3. № 6. С. 83-89.

6. Самченко Т. В. Оцінка джерел надходження радіонуклідів до організму мешканців сільських територій Полісся України : дис. ... д-р філософії : 261 / ЧІПБ ім. Героїв Чорнобиля НУЦЗ України. Черкаси, 2020. 171 с.

7. Методи математичного моделювання теплових процесів при випробуваннях на вогнестійкість залізобетонних будівельних конструкцій : монографія / О. М. Нуянзін та ін. Черкаси, 2015. 120 с.

8. Pozdieiev S. et al. Computational study of bearing walls fire resistance tests efficiency using different combustion furnaces configurations. MATEC Web of Conferences. EDP Sciences, 2017. T. 116. C. 02027.

\section{REFERENCES}

1. Rojtman V. M. (2001). Inzhenernye resheniya po ocenke ognestojkosti proektiruemyh i rekonstruiruemyh zdanij. M. : Associaciya «Pozharnaya bezopasnost' i nauka» [Engineering solutions for assessing the fire resistance of projected and reconstructed buildings]. M.: Association «Fire safety and science». 382 p. [in Russian].

2. DSTU B V.1.1-4-98. Zakhyst vid pozhezhi. Budivelni konstruktsiyi. Metody vyprobuvannia na vohnestiykist. Zahalni vymohy (ISO 834:1975) (1999). [Fire protection. Building constructions. Fire resistance test methods. General requirements]. Kyiv: Ukrarkhbudynform, $21 \mathrm{~s}$. [in Ukrainian].

3. DSTU-N EN 1991-1-2:2010 Yevrokod 1: Dii na konstruktsii - Chastyna 1-2: Zahalni dii - Dii na konstruktsii pid chas pozhezhi [Eurocode 1: Actions on structures - Part 1-2: General actions -Actions on structures exposed to fire] [in Ukrainian].

4. EN 1992-1-2:2004+A1:2019 (2019). Eurocode 2: Design of concrete structures Part 1-2: General rules. Structural fire design, Brussels. 118 p. [in English].

5. Nuianzin, O. M., Samchenko T. V., Peregin A. V., Krishtal V. M. (2019). Povnyi faktornyi eksperyment z vyznachennia temperaturnykh rezhymiv pozhezhi u kabelnykh tuneliakh [A new factorial experiment on the determination of temperature conditions in the fire near cable tunnels]. Nadzvychaini sytuatsii : poperedzhennia ta likvidatsiia. T. 3. № 6. S. $83-89$ [in Ukrainian].

6. Samchenko T. V. (2020). Otsinka dzherel nadkhodzhennia radionuklidiv do orhanizmu meshkantsiv silskykh terytorii Polissia Ukrainy [Estimation of sources of receipt of radionuclides to an organism of inhabitants of rural territories of Polissya of Ukraine]: Thesis ... Dr. of Philosophy: 261 / CHIPB them. Heroes of Chernobyl NUTSZ of Ukraine. Cherkasy. 171 p. Metody matematychnoho modeliuvannia teplovykh protsesiv pry vyprobuvanniakh na vohnestiikist zalizobetonnykh budivelnykh konstruktsii : monohrafiia [in Ukrainian].

7. Nuianzin O. M., Nekora O. V., Pozdieiev S. V. [ta in.] (2019). Metody matematychnoho modeliuvannia teplovykh protsesiv pry vyprobuvanniakh na vohnestiikist zalizobetonnykh budivelnykh konstruktsii : monohrafiia [Methods of Mathematical Modeling of Thermal Processes in Viprobavannyh on the fire of concrete alarm constructions : monograph]. Cherkasy: ChIPB im. Heroes of Chornobil NUTSZ Ukraine. 120 p. [in Ukrainian].

8. Pozdieiev S. et al. (2019). Computational study of bearing walls fire resistance tests efficiency using different combustion furnaces configurations. MATEC Web of Conferences. EDP Sciences, 2017. T. 116. P. 02027 [in English]. 


\title{
SCIENTIFIC SUBSTANTIATION OF THE METHOD OF CALCULATION ASSESSMENT OF THE CLASS OF FIRE RESISTANCE OF BUILDING STRUCTURES OF CABLE TUNNELS
}

\author{
O. Nuianzin ${ }^{1}$, T. Samchenko ${ }^{2}$, V. Nuianzin ${ }^{1}$, A. Maiboroda ${ }^{1}$ \\ ${ }^{1}$ Cherkasy Institute of Fire Safety named after Chernobyl Heroes National University of Civil Defence of \\ Ukraine \\ ${ }^{2}$ Institute of Public Administration and Research in Civil Protection, Ukraine
}

\section{KEYWORDS}

cable tunnel, fire temperature mode, computer modeling, building constructions, fire resistance class

\begin{abstract}
ANNOTATION
Cable tunnels differ in geometric configuration, type of cables laid in them, fire load and aerodynamic characteristics. This can lead to the fact that the temperature of the fire in such tunnels may differ from the standard and from each other. In this case, it is not possible to guarantee compliance of the limits of fire resistance of the tested structures with the current standards. In this work, the temperature regimes of heating reinforced concrete enclosing structures of different thickness $(40 \mathrm{~mm} ; 60 \mathrm{~mm} ; 80 \mathrm{~mm} ; 100 \mathrm{~mm})$ of cable tunnel at constant values of specific heat of combustion of fire load, cross-sectional area of cable tunnel and horizontal air velocity component are calculated. The calculation of fire resistance of building structures of the wall of the cable tunnel fence with a thickness of: $40 \mathrm{~mm} ; 60 \mathrm{~mm} ; 80 \mathrm{~mm} ; 100 \mathrm{~mm}$ is conducted. To perform a calculated assessment of the fire resistance of reinforcing concrete structures of cable tunnels using the proposed temperature regimes of the fire, the heating temperature of the fence at any time of the fire was determined. The obtained data shows that not all barriers will meet the requirements of fire resistance classes EI 30, EI 45 and EI 60. The advantages of the proposed approach have been proven, as it allows to justify much higher fire resistance classes for fences smaller than $80 \mathrm{~mm}$. Based on the results of the work, the calculation algorithm is scientifically substantiated and verified, and the method of calculation assessment of the fire resistance class of building structures of cable tunnels based on mathematical modeling is developed on its basis. During the calculation, temperature distributions are constructed along the cross section of the cable tunnel fence at a time that corresponds to the required fire resistance class. If the temperature on the unheated side does not exceed $140 \mathrm{C}$, it can be concluded that it complies or does not comply with the required fire resistance class. In view of the conducted research, recommendations were proposed for the estimated assessment of fire resistance of reinforced concrete enclosing structures of cable tunnels. The developed technique is based on the following procedures.
\end{abstract}

